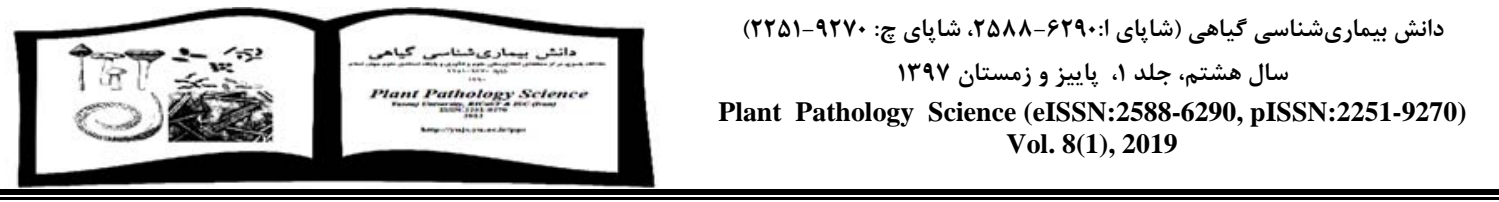

\title{
Root Knot Disease of Pomegranate
}

\author{
MARYAM HATAMABADI-FARAHANI
}

Research Institute of Plant Protection, Agricultural Research, Education and Organization (AREEO), Arak, Iran (Maryamhatami2002@yahoo.com)

Received: 07.05.2018

Accepted: 18.11.2018

Hatamabadi-Farahani M. 2019. Root knot disease of pomegranate. Plant Pathology Science 8(1):38-49. DOI:10.2982/PPS.8.1.38.

Abstract: Pomegranate is an important fruit crop which is attacked by several pests and pathogens. Diseases caused by nematodes are of economic importance. The root knot nematodes (Meloidogyne spp.) causing considerable yield losses in pomegranate. Root knot nematodes are sedentary endoparasite that are basically parasites of the roots, produces knots on root which cause weak root function in the absorption and transfer of water and nutrient. Above ground symptoms include dwarfing the plants, yellowing and reduction of foliage, falling leaves and yield losses. Under favorable temperature and moisture, eggs are hatching and second stage pathogenic juveniles are released. The management strategies are including sanitation, construction of nursery in healthy areas, annual plowing of garden, drip irrigation, soil solarization, organic amendment of soil and strengthen the trees.

Key words: Endoparasite, Management, Meloidogyne

$$
\begin{aligned}
& \text { بيمارى غده ريشه انار } \\
& \text { مريهم حاتم آبادى فر اهانى } \\
& \text { بخش تحقيقات كياهيزشكى، مركز تحقيقات و آموزش كشاورزى و منابع طبيعى استان مركزى، سازمان } \\
& \text { تحقيقات، آموزش و ترويج كشاوزى،، اراك، ايران } \\
& \text { دريافت: }
\end{aligned}
$$


نتيجه در قسمتهاى هوايى درخت نشانههاى توقف رشد، ضـف عمـومى، زردى و ريـزش بـرىهـا و خشك شدن تدريجى سرشاخهها همراه با كاهش عملكرد ديده مىشود. در شرايط مناسـب رطوبـت و حرارت تخمهاى نماتد تفريخ و لارو سن دوم از آنها خارج مىشود. لاروهاى سن دوم موجود در خـاك مرحله بيماركر اين نماتدها مىباشند. مديريت اين بيمارى به روش رعايت اصول بهداشتى، مراقبـت از باغهاى سالم، احداث نهالستان در مناطق سالم، شخمى ساليانه باغ، استفاده از سيستم آبيارى قطـرهاى، آفتابدهى خاك، بالا بردن ميزان مواد آلى خاى و تقويت درختان مىباشد. وازه هاى كليدى: انكل داخلى، مديريت، Meloidogyne

مقدمه

انار با نام علمى (Punica granatum L.) درخت يا درختجهاى بزرگ، يرشاخ و برگ با پاجوشهاى زياد از شاخه پِيدازادان، رده نهاندانعان، دوليهاى و متعلق به تيره Punicaceae است. درخت انار اصولاً يك ميوه گرمسيرى تا نيمه گرمسيرى است و در نواحى ساحلى و مرطوب به صورت درخت هميشه سبز مىباشد ولى در نواحى خشك با زمستانهاى سخت به صورت درخت خزاندار است. مناطق حاشيه كوير، با تابستانهاى گرم و خشك و آب و خاك نسبتاً شور، مناطق اصلى كشت و كار و توليد اقتصادى انار كشور را تشكيل مىدهند. از جمله ويزگىهاى با ارزش اين گياه، انعطافيذيرى آن نسبت به انواع خاكها و تحمل كم آبى و شورى آب و خاك مىباشد (شاكرى

درختان انار نيز مانند ديكر درختان ميوه از حمله آفات و امراض در امان نبوده و هر ساله خسارت هنخفتى ناشى از آنها به باغهاى انار وارد مىشود. يكى از اين عوامل خسارتزا نماتدهاى بيماريزاى كَاهى هستند، موجودات باريك و كشيده كرمى شكل كه در خاك اطراف ريشه گياه زندگى مى كنند و در بين آنها نماتد غده ريشه بيشترين خسارت را مىزند. نماتدهاى غده ريشه( Meloidogyne (spp. و درجه حساسيت ميزبان مىتوانند در اكثر مزارع و باغها ايجاد خسارت اقتصادى نمايند IV/T (M. incognita) كاهش عملكرد محصول انار ناشى از نماتد غده ريشه (Perry et al. 2009) درصد ززارش شده است (Jain et al. 2010). اين نماتد به عنوان مشكل جدى انار در بيشتر كشورهايى كه در آن كشت مىشود كزارش شده است (Rich et al. 2006).

\section{ا- موقعيت آرايه بندى و شكلشناسى نماتدهاى غده ريشه}

نماتدهاى غده ريشه از نظر آرايهبندى به شاخه نماتدها (Nematoda)، رده Chromadorea، 


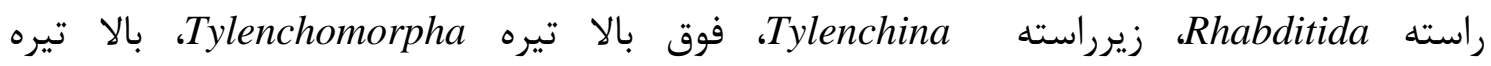
Meloidogynidae، زيرتيره Meloidogyninae، و جنس Meloidogyneidea مىباشند (Perry and Moens 2013). اولين نماتد غده ريشه در سال 1 1 ا ميلادى توسط بركلى در انگلستان از روى ريشه خيار كلخانهاى گزارش شد (Jepson 1987) و در ايران اولين بار در سال هسبا توسط قوامالدين شريف از روى ريشه گوجهفرنغى در قصر شيرين گزارش گرديد (مهديخانى و فلاحتى

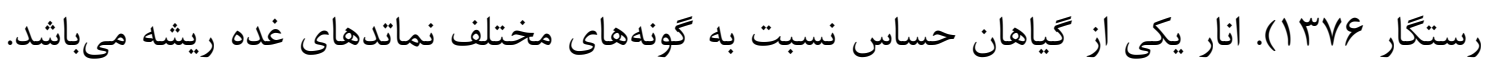

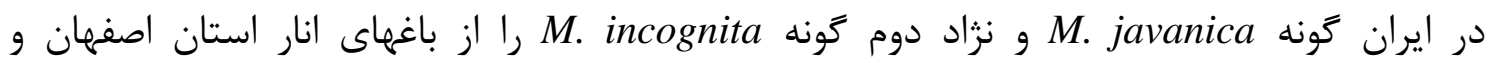
M. javanica

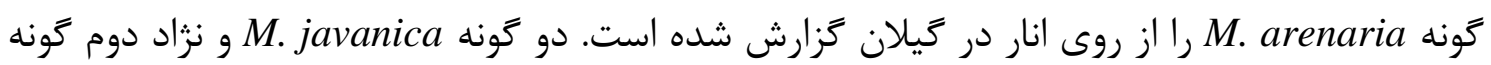
M. incognita

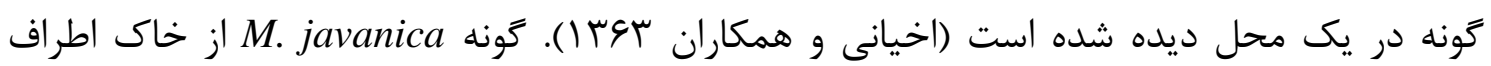
ريشه درختان انار در شهرستانهاى تهران و شميرانات، ساوه و قم و M. incognita از شهرستانهاى

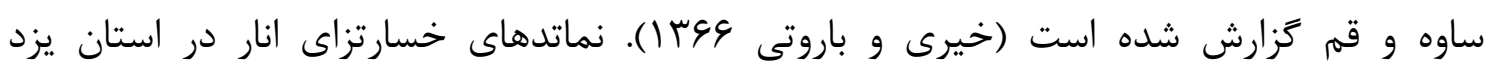

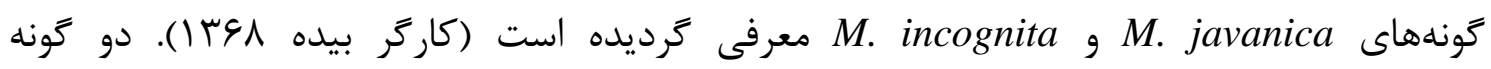
M. incognita در باغهاى انار شهرستان ساوه معرفى شدهاند و گونه M. javanica M. incognita

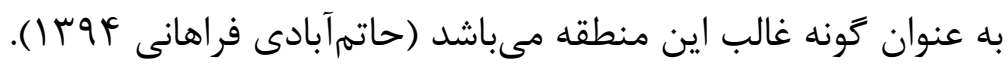
نماتدهاى غده ريشه داراى دو شكلى جنسى نر و ماده مىباشند. نماتد ماده كيسهاى تا كروى

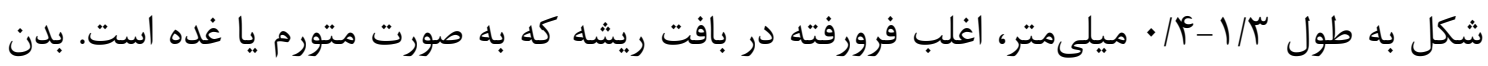
نرم، سفيدرنت، گردن از سمت جلويى توسعه يافته و منفذ ترشحى در جلوى حباب ميانى مرى، اغلب نزديك يايه تيغه، منفذ تناسلى ماده و مخرج، انتهايى بوده كه هم سطح با بدن و يا مقدارى از سطح Perineal ( بالاتر است. كوتيكول قسمت انتهايى، تشكيل يك حالت تفكيكى به نام اثر انگشت

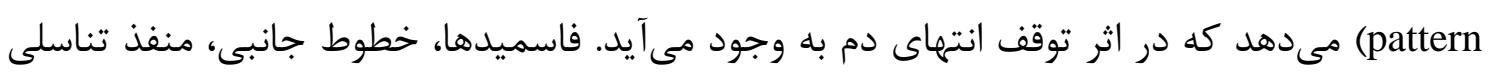
و مخرج توسط شيارهاى كوتيكولى احاطه مىشوند. اثر انخشت اغلب يك ويزگى تفكيكى براى گونهها مىباشد. سلولهاى جنسى جفت و داراى تخمدانهاى كسترده و يِيجيده كه اكثر حفره بدن را احاطه مى كند. شش غده تك سلولى مخرجى بزرى در انتهاى بدن وجود دارد كه يك توده زلاتينى توليد مى كنند. اين غدهها از طريق راست روده، ترشح شده و تشكيل يك كيسه تخم را مىدهد (نصراصفهانى و احمدى 1 1 (1). در شرايط مطلوب جند صد تخم درون كيسه تخم تشكيل مىشود 
(Anwar and McKenry 2007). نماتدهاى نر كرمى شكل، اندازه آنها بين V/ • تا ا 19/ ميلىمتر متغير است. شبكه كوتيكولى سر ضعيفتر از گونههاى Heterodera است. لاروهاى آلوده كننده سن دو، اغلب به صورت آزاد در خاك بوده و طول آنها ه/ •-r/• ميكرون است. لاروها شبكه كوتيكولى سر ضعيفى دارند. حباب ميانى مرى به خوبى توسعه يافته، غدد مرى گسترده و جند برابر عرض بدن و از سمت شكمى با روده هميوشانى دارد. دم مخروطى شكل و اغلب به يك انتهاى باريك گرد ختم مىشود. ولى طول دم متغير بوده و بين گونهاى متفاوت V-V/D برابر عرض بدن در ناحيه مخرج، انتهاى دم داراى يك بخش شفاف و روشن است كه اندازه آن به تفكيك گونهها كمك مىنمايد

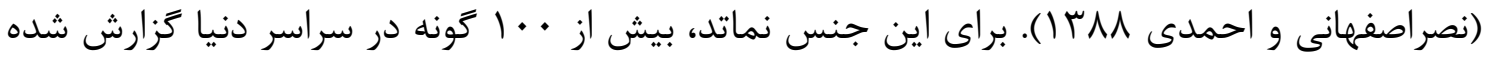
است (Hunt and Handoo 2009, Onkendi et al. 2014) ولى مهممترين گونههاى آن عبارتند از و M. hapla M. arenaria M. incognita ،M. javanica عامل بيش از هو درصد آلودگىهاى حاصل از نماتدهاى غده ريشه در زمينهاى كشاورزى را شامل مىشوند (Cenis 1993, Hunt and Handoo 2009).

\section{ץ- زيست شناسى نماتدهاى غده ريشه}

نماتدهاى غده ريشه بيماركر اجبارى، انكل داخلى ريشه، غير مهاجر يا ساكن مىباشند. در شرايط مناسب رطوبت و حرارت (بالاى بr درجه سانتى خارج شده (لارو سن يك در داخل تخم به وجود مىآيد اما از تخم خارج نمىشود) و وارد خاك مى گردد. اين لاروها بسيار ريز و متحرك بوده و در خاك مرطوب به صورت زندگى آزاد و غير انگلى با جريان آب در داخل خلل و فرج ذرات خاى به دنبال ميزبان حركت مىكنند. در صورت عدم دسترسى به ميزبان اين لاروها مىتوانند به حالت كمون بدون تغذيه در شرايط نامناسب بيش از يك سال به صورت زنده در داخل خاك دوام بياورند؛ بنابراين لاروهاى سن دوم موجود در خاك مرحله بيماركر اين نماتد مىباشند. انتشار اين نماتد به وسيله ريشهها، آب، انتقال خاك و نهال آلوده و ادوات كشاورزى صورت مى گيرد. لاروهاى سن دوم به محض برخورد با ريشههاى فرعى گياه ميزبان به داخل آنها نفوذ نموده يس از تغذيه و يوست اندازى تحرك خود را از دست داده، در نزديكى استوانه مركزى مستقر و متورم شده و در داخل به حالت سر به طرف مركز و دم به طرف خارج ريشه ساكن گشته زندگى انكلى خود را آغاز مىنمايند. اين لاروها يس از حذرانيدن دو سن لاروى ديگر يعنى لارو سن ب و أ، بالغ مىشوند. نماتدهاى نر كه از سن سوم قابل تشخيص هستند يس از بلوغ كرمى شكل و متحرك شده، آنعاه از ريشه خارج و جهت جفتگيرى در داخل خاك اطراف مادهاى جسبيده به 
ريشه به فعاليت مىيردازند. نماتدهاى ماده يس از جفتخيرى اقدام به تخم ريزى مىنمايند. اين نماتدها با استفاده از خاصيت توليدمثل دخترى (Parthenogenesis) بدون جفتخيرى با نماتد نر، قادر به تخمريزى و توليد نماتدهاى نر و ماده بوده و بدين ترتيب ادامه نسل مىدهند. تشكيل يك نسل كامل انگل در حرارت VV درجه سانتى

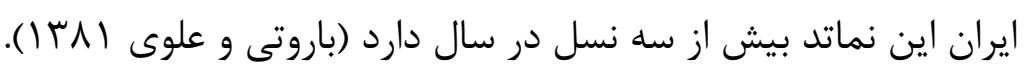

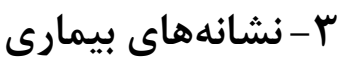

نماتدهاى غده ريشه انگل داخلى ساكن ريشه هستند كه يس از ورود به بافت ريشه باعث ايجاد تغييرات فيزيولوزيكى و بيوشيميايى در زياه ميزبان شده و در نتيجه باعث توقف رشد، ضعف عمومى، زردى بركها، ريزش بركهاى فوقانى، لخت و خشك شدن تدريجى سرشاخهها و بالاخره غدهاى شدن توأم با يوسيدگى عمومى ريشه شده و موجبات مرگ تدريجى درختان را فراهم مى آورد (اخيانى

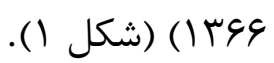
اين نماتدها با نفوذ به داخل ريشه و با ترشحات آنزيمى مخصوص خود از جمله يروتئزاز، متابوليسم ميزبان را به نفع خود تغيير مىدهند. گياه ميزبان نيز با عكس العمل خود و ايجاد خاصيت بزرى شدن سلولها (Hypertrophy) و ازدياد سلولى (Hyperplasia) در بافت ريشه با سنتز اكسين و ساير مواد

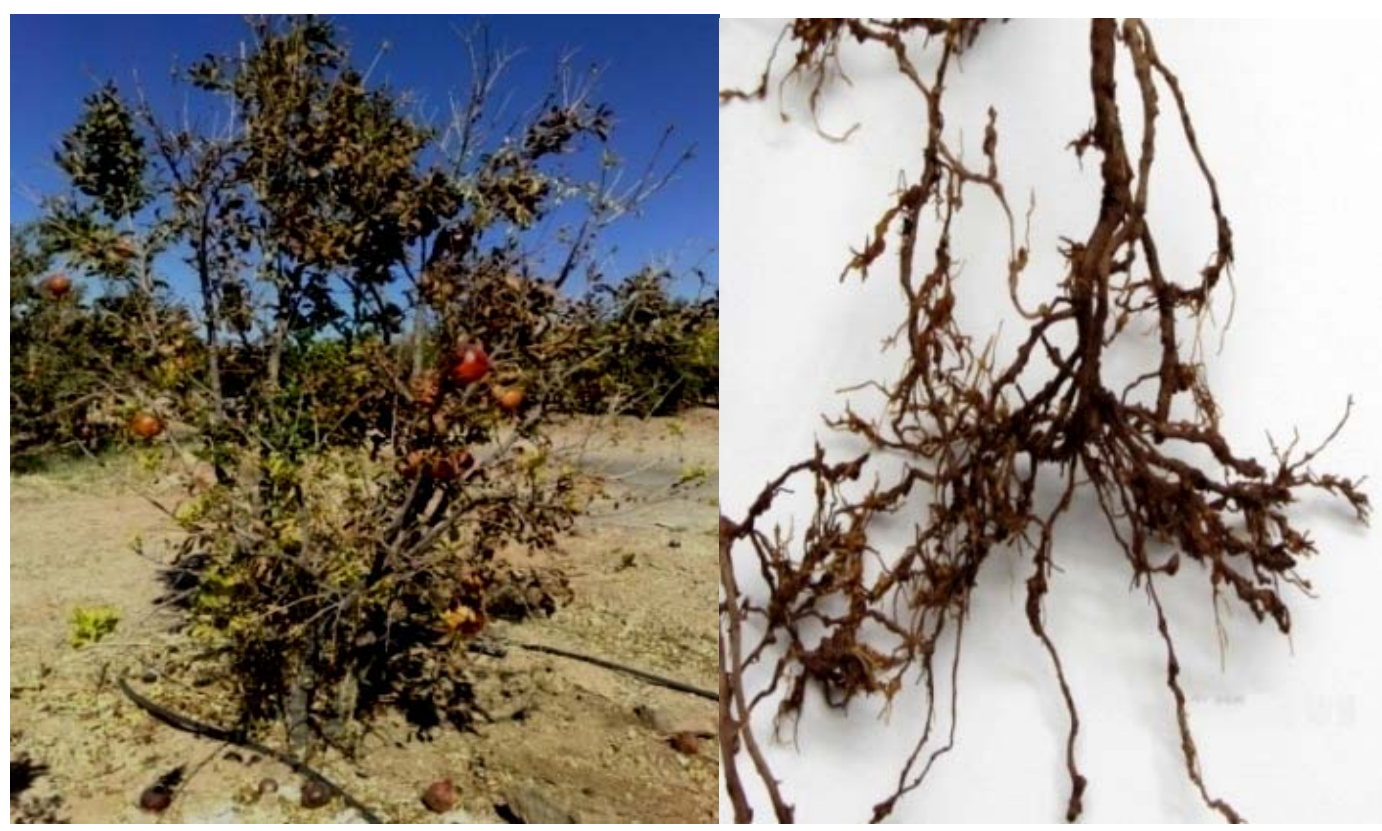

شكل ا. غدههاى روى ريشه و خشكيدگى سرشاخهها در درختان انار آلوده به نماتد غده ريشه(اصلى)

Figure 1. Knotted root and dieback in the pomegranate tree infested with root knot nematode (original) 
يا هورمونهاى رشدى به مقابله برخاسته و در نتيجه از حالت طبيعى خارج مىگردند. اطراف نماتدهاى مهاجهم را سلولهاى زيادى احاطه مىنمايند كه منجر به تشكيل غده روى ريشه مىشود. ريشه گياه ميزبان نمىتواند وظايف اصلى خود يعنى رشد طبيعى و تامين مواد غذايى از طريق جذب مواد از خاك را به خوبى انجام دهد (باروتى و علوى IN II). بافت سبك تا نيمه سبك خاكهاى اكثر باغهاى انار نيز از عوامل تشديد كننده خسارت اين نماتد مىباشد. با آنكه بيشتر باغهاى انار كشور به اين نماتد آلوده مىباشند، اما قدرت ريشهزنى زياد درختان انار و هرس ريشه كه طى فرآيند شخم يا بيل دارى و جال كود كردن انجام مىشود از شدت خسارت كاسته و موجب بازسازى سيستم ريشه مىشود. به همين جهت باغداران جندان شكايتى از خسارت اين نماتد ندارند. عليرغم اين مطلب آثار فعاليت اين نماتد بصورت خشكيدگى سرشاخهها در باغهايى كه جمعيت نماتد زياد و مديريت باغ ضعيف بوده قابل رويت مىباشد (شاكرى r r I ).

\section{F - مديريت بيمارى}

مديريت بيمارى اساساً مبتنى بر ييشخيرى است. اقدامهاى زير جهت جلوگيرى از گسترش

نماتدهاى غده ريشه در مناطق آلوده پيششنهاد شدهاند (Guerena 2006).

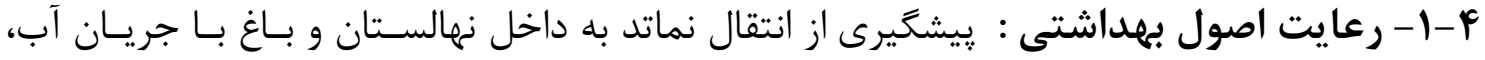
حيوانات، بقاياى آلوده كياهى، ادوات كشاورزى، نهال، خاى آلوده جهت خاكدهى يـاى ريشـه و غيــه (Guerena 2006, Mulrooney 2004). جداسازى و ريشهكنى نقاط آلوده به نماتدها، بايد حتما نواحى آلوده به نماتد و درختان بيمارى كه به شدت آلوده شدهاند را ايزوله يـا جداسـازى و درختـان بشـدت آلوده را معدوم كرد جون نماتدها بسهولت از طريق آب آبيارى از درختان آلوده به درختان سالم انتقال مى يابند. يرهيز از كشت نهال آلوده با بررسى ريشههاى آن (Guerena 2006). كنترل مسير آبيارى به طورى كه جريان آب از زمينهاى آلوده عبور نكند (Mulrooney 2004). F-F-F احداث نهالستان در مناطق سالم : نهالها بايد در بستر عارى از تخم و لارو نماتد غده ريشه توليد شوند (Perry et al. 2009). F-F- بالا بردن ميزان مواد آلى خاك و تقويت درختان: افزودن مواد آلى نظير كود حيوانات اهلى و بقاياى كياهى به خاك يس از برداشت، جمعيت نماتد و لارو سن دوم آن را كاهش مى دهد و همجنين جمعيت نماتدهاى آزادزى و گونههاى نماتدخوار افزايش مىيابد و در نهايت سبب رشد و نمو كياه مىشود (Whitehead 1997, Walker 2004). طى يك آزمايش، اضافه كردن كميوست به خاك 
مزرعه كشت سيب زمينى باعث كاهش معنى دار جمعيت نماتد M. hapla نسبت به مزرعه سيب زمينى بدون افزودن كميوست شد (Kimpinski et al. 2003).

F-F-F - F استفاده از سيستم آبيارى قطرهاى : نماتدها در شرايط تنش آبى بيشتر خسارت مىزنند لذا آبيارى كافى و افزايش ظرفيت نتحهدارى آب در خاى مىتواند به كاهش خسارت ناشى از نماتد كمك كند (Perry and Ploeg 2010). با توجه به اين كه جريان آب هم مى تواند عامل انتقال نماتد در سطح باغ باشد، تغيير سيستم آبيارى از غرقابى به قطرهاى علاوه بر صرفهجويى در مصرف آب باعث كاهش انتقال نماتد نيز خواهد شد. در آزمايش بررسى تاثير آبيارى قطره اى و نماتدكش، آبيارى قطره اي به تنهايى جمعيت نماتدهاى Xiphinema و Pratylenchus را در ريشه هاى نهال هاى هلو كاهش داد (Funt et al. 1982).

F-1 - آفتاب دهى خاك : استفاده از يلاستيكهاى شفاف در سطح خاك مرطوب در طول تابستان

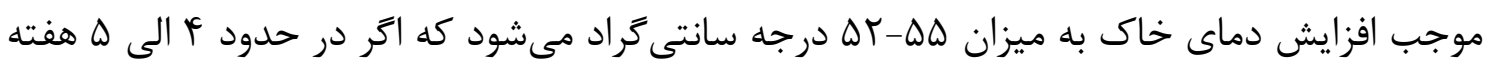
به اجرا درآيد، تاثير خوبى در كاهش جمعيت اين نماتدها دارد. در بعضى كشورها، اين روش به همراه كود حيوانى تازه در كنترل نماتدها مورد استفاده قرار كرفته است (Chen 2004,Whitehead 1997). F-4- اجتناب از كشت درختان اناردر خاك هاى خيلى سبك و ماسهاى : بر خلاف آنجه كه مرسوم است، خاكهاى بسيار سبك كزينه مناسبى براى احداث باغ انار نبوده به اين دليل كه فعاليت اين عامل بيمارى در خاكهاى سبك و ماسهاى بيشتر بوده و باعث ايجاد خسارتهايى بر ريشه درختان مىشود. خاكهاى سبك و شنى به دليل داشتن فضاهاى خالى بيشتر و هوادهى كارآمدتر نسبت به خاكهاى رسى و سهولت حركت نماتد در منطقه ريشه، جمعيت هاى بيشترى از اين عامل بيمارى را در خود جاى مى دهند (Guerena 2006). مبارزه با علفهاى هرز در باغ هاى جديدالاحداث : مبسيارى از علفهاىهرز ميزبان -V-F نماتدهاى غده ريشهرستند و باعث افزايش جمعيت آن در باغ مىشوند. از بين بردن ميزبانهاى علفهرز گسترش بيمارى را كاهش خواهد داد (Yepsen 1984). F-1-F- شخم ساليانه باغها : شخم ساليانه باعث مىشود ريشهاى سطحى درختان هرس شده وتوسعه ريشههاى عميقتر آسان شود. شخم عميق • ا تا · r سانتىمترى خاك در سه نوبت، هر دو

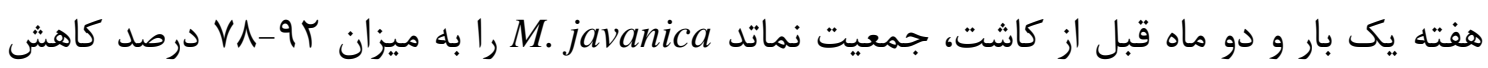
داده است (Whitehead 1997). 
F-9- مبارزه شيميايى : با توجه به خصوصيات ارزشمند درختان انار از جمله قدرت ريشهزنى زياد و وجود ذخائر غنى زنتيكى انار در كشور و همجنين امكان به كاركيرى تدابير زراعى، به نظر نمىرسد كه آلوده ساختن باغهاى انار به سموم شيميايى ضرورت داشته باشد. علاوه بر هزينههاى كزاف مبارزه

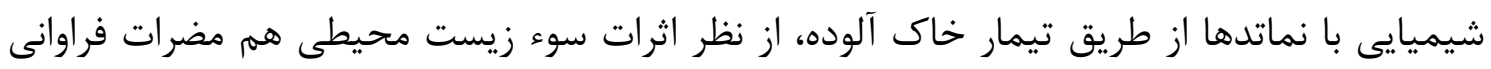

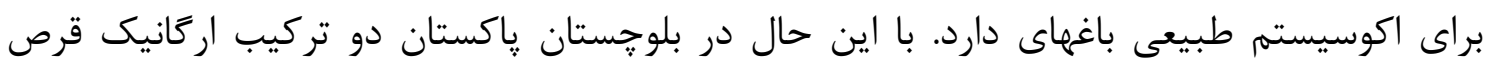
روغن خردل و كرجك و سم كربوفوران باعث كاهش جمعيت نماتدهاى مرتبط با انار شدند اما روى عملكرد تاثيرى نداشتند (Khan et al. 2011). در يك بررسى در جين سم 3\% Miral (ايسازوفوس) كرانوله باعث كاهش جمعيت M. incognita در باغهاى انار شد (Yunzhong 2007). امروزه به دليل زيانهاى ناشى از مصرف بىرويه سموم شيميايى، توجه به استفاده از مواد كياهى از اهميت ويزهاى برخوردار كرديده است. نتايج يزوهشهاى انجام شده با كاربرد روغن، عصاره و يودر مغز بذر و كنجاله جريش، عصاره و يودر بذر كامل زيتون تلخ، عصاره و يودر قسمتهاى هوايى بومادران مىتوان به نحو موثرى با نماتد M. incognita عامل بيمارى غده ريشه كوجه فرنكى مبارزه كرد (صلاحى اردكانى و حسينى نزاد •وج(ا). بر اساس نتايج بركرفته از تحقيقات، كَياه كل جعفرى به دليل داشتن خاصيت توكسينى، توانايى بسيارى در مهار نماتدهاى غده ريشهو كاهش جمعيت آنها دارا مىباشد. كشت كل جعفرى طى هندين فصل متوالى باعث كاهش جمعيت الهي نماتد و افزايش حدود •هـ/ محصول گوجه فرنكى شده است (ابوترابى لهوبا ). ץ-^•|- استفاده از ارقام مقاوم يا متحمل نسبت به نماتد: هم اكنون بكاركيرى ارقام مقاوم بر عليه نماتدها كاملا رايج شده است. تجارب علمى نشان داده است كه هرجه روابط نماتد و ميزبان

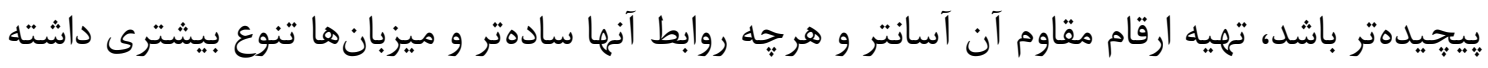

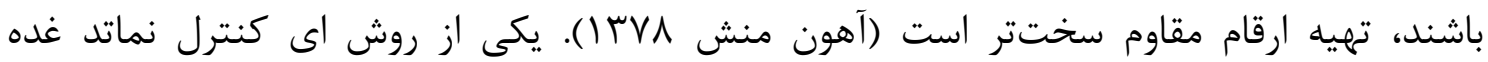

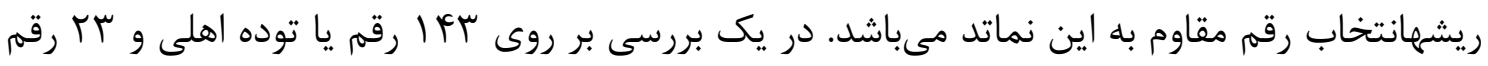
يا توده وحشى انار در رابطه با عكس العمل آنها نسبت به كَنه M. javanica (كونه غالب اين نماتد در كشور) در شرايط مزرعه، VI رقم اهلى و 9 توده وحشى به عنوان انواع متحمل انار نسبت به اين كونه شناخته شدهاند(اخيانى و مجتهدى لهوبا). نتيجه آزمايشى روى ارقام مختلف انار نسبت به نماتد M. incognita

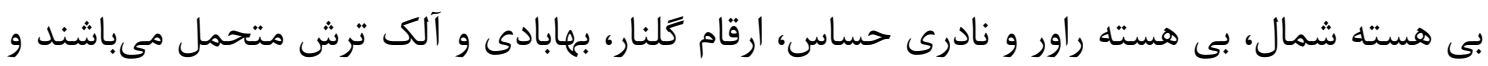


ارقام آقا محمدعلى، ملس شيرين، شهسوار يزدى، سوسكى تفت و تابستانى مقاوم شناخته شدند

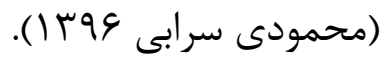

در مجموع مديريت صحيح باغ و هر عملى كه در جهت تقويت درختان صورت بخيرد شامل كود دادن به موقع، آبيارى صحيح، شخم زدن و كاهش تنشها مىتواند باعث كاهش خسارت اين بيمارى گردد (Mulrooney 2004). در مورد باغهاى جديد الاحداث آلودگى نهالهاى جوان انار به نماتدهاى ريشه كرهى، از توسعه و نفوذ ريشه درخت به عمق مناسب جلوگيرى و با افزايش تدريجى جمعيت بيمارى در خاك، باعث مرى گياه مىشود. ولى جنانجه در سالهاى اوليه استقرار شرايطى فراهم باشد تا درخت بتواند به قدر كافى ريشههاى خود را در خاك گسترش دهد يا به تعبيرى ريشه از ناحيه فعاليت نماتدها فرار كرده و به اعماق بيشتر از •ه سانتىمتر نفوذ كند و گِس از آن نيز وضعيت نكمهارى باغ در جهت تقويت درخت باشد كياه مىتواند فشار ناشى از نماتد را تحمل و به مرز توليد اقتصادى برسد. اين دوره استقرار براى درختان انار V-D سال خواهد بود. درختان انار يس از استقرار، در صورت آلودگى قادر به تحمل خسارت نماتد بوده به شرط آنكه شرايط رسيدگى باغ خوب باشد

(شاكرى (1) (1).

\section{نتيجه كيرى}

انار يكى از كياهان حساس نسبت به نماتدهاى غده ريشه (Meloidogyne spp)(است. نماتدهاى

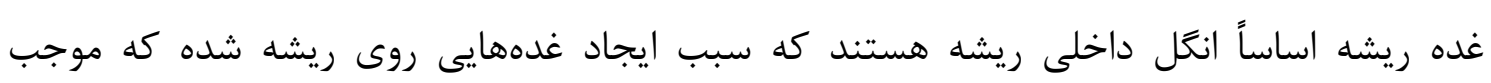
اختلال در عملكرد ريشه و جذب آب و مواد غذايى مىشوند كه در قسمتهاى هوايى درخت به صورت زردى، خشك شدن و ريزش برگها، ضعف گياه و كاهش عملكرد نمايان مى گردد. بهترين روش مبارزه با بيمارى غده ريشه انار ممانعت از ورود آن به باغهاى سالم از طريق رعايت اصول بهداشتى و كاشت ارقام مقاوم مىباشد و در باغهاى آلوده، بالا بردن ميزان مواد آلى خاك و تقويت درختان، استفاده از سيستم آبيارى قطرهاى، آفتابدهى خاك، شخم ساليانه باغ و مبارزه شيميايى با استفاده از سموم شيميايى يا گياهى باعث كاهش عوارض ناشى از حمله نماتد مى گردد. از آنجايى كه نماتدها در شرايط تنش آبى و ضعف درخت بيشتر خسارت مىزنند بنابراين مديريت صحيح باغ و تقويت درختان در جهت كاهش خسارت اين بيمارى قيشنهاد مى گردد.

\section{References}

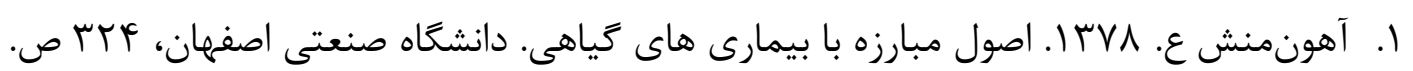


ז. ابوترابى ا. لهوسا. معرفى جهار گونه گل جعفرى مهاركننده نماتدهاى غده ريشه. دانش بيمارى

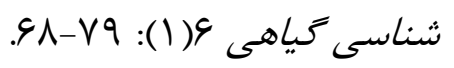

س. اخيانى ا.، مجتهدى ح. و نادرى ا. بعسا. تونه ها و نزادهاى فيزيولوزيك نماتدهاى مولد غده ريشه

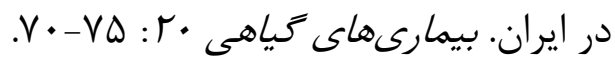

f. اخيانى ا. و مجتهدى ح. هوسا. برترى مقاومت انار نسبت به نماتد مولد غده ريشه (Meloidogyne javanica)

$$
\text { كشاورزى دانشخاه صنعتى اصفهان، ايران، ص هـ ا. }
$$

ه. اخيانى ا. وצسا. آفات و بيمارىهاى مهلم انار در استان هاى يزد و اصفهان. معرفى مقالات اولين سمينار بررسى مسائل انار در ايران، جهاد دانشخاهى دانشكده هاى كشاورزى و منابع طبيعى

$$
\text { دانشعاه تهران، كرج. }
$$

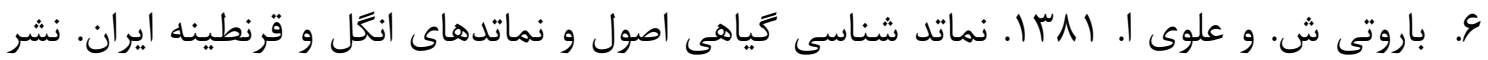

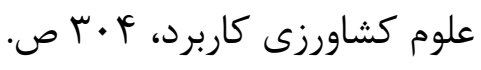

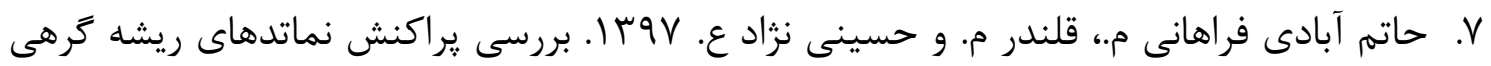
در باغات انار شهرستان ساوه. خلاصه مقالات بيست و سومين كنگره گياهيزشكى ايران، گر گان. VTd 1. خيرى ا. و باروتى ش. وعسا. معرفى نماتدهاى پارازيت كياهى جمع آورى شده از خاكهاى اطراف ريشه درختان انار. معرفى مقالات اولين سمينار بررسى مسائل انار در ايران، جهاد دانشخاهى دانشكده هاى كشاورزى و منابع طبيعى دانشخاه تهران، كرج، ص 19.

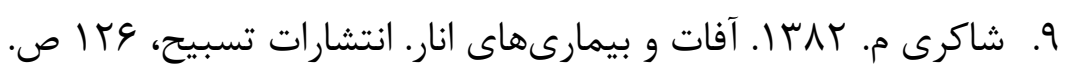
ا. صلاحى اردكانى ع. و حسينى نزاد س.ع. • وبا. كاربرد بومادران، زيتون تلخ و ¥ريش در مبارزه با نماتد غده ريشه Meloidogyne incognita دانش بيمارى شناسى كياهى |(1): צץ-4F|. • ا.كاركر بيده ا. ^عץ ا. بررسى فون نماتدهاى زيان آور درختان ميوه (انار، پسته و بادام) در استان يزد. يايان نامه كارشناسى ارشد، دانشكده كشاورزى دانشگاه تربيت مدرس، • If ص. ال.محمودى سرابى م. عوبا. واكنش ارقام مختلف انار نسبت به نماتد ريشه گرهى. پايان نامه

$$
\text { كارشناسى ارشد، دانشكده كشاورزى دانشعاه شهركرد، له ص. ص. }
$$

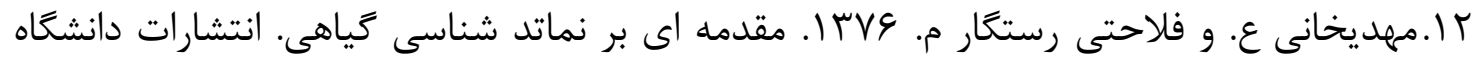

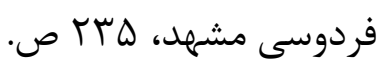




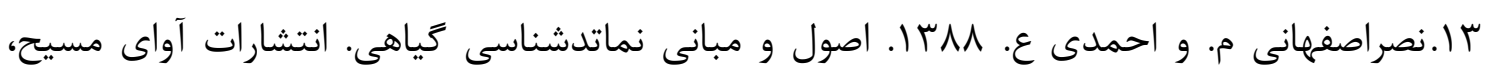

ص ص

14. Anwar S. A. and McKenry M. V. 2007. Variability in reproduction of four populations of Meloidogyne incognita on six cultivars of cotton. Journal of Nematology 39:105-110.

15. Cenis J. L. 1993. Identification of four major Meloidogyne spp. by random amplified polymorphic DNA (RAPD-PCR). Phytopathology 83:76.

16. Chen Z. X., Chen S. Y. and Dikson D. W. 2004. Plant nematology biology, morphology (vol.1) and nematode management and utilization (Vol.2). CABI Publishing, 2000p.

17. Funt R. C., Krusberg L. R., Ross D. S. and Goulart B. L. 1982. Effect of post-plant nematicides and trickle irrigation on newly planted peach trees. Journal of the American Society for Horticultural Science 107:891-895.

18. Guerena M. 2006. Nematodes: alternative controls. http:/attra.ncat.org/attrapub/PDF/nematode.pdf. Accessed 15 April 2008.

19. Hunt D. J. and Hundoo Z. A. 2009. Taxonomy, identification and principal species. Pp:55-97. In: R. N. Perry, M. Moens and J. L. Starr. Root-knot nematodes (ed.). CABI, Wallingford, UK.

20. Jain R. K., Mathur K. N. and Singh R. V. 2010. Estimation of losses due to plant parasitic nematodes on different crops in India. Indian Journal of Nematology 37:219-221.

21. Jepson S. B. 1987. Identification of root-knot nematodes Meloidogyne species. CABI Publishing, 265p.

22. Khan A., Shaukat S. S. and Sayed M. 2011. Management of plant nematodes associated with pomegranate using oil-cakes in Balochistan, Pakistan. Indian Journal of Nematology 41:1-3.

23. Kimpinski J., Gallant C. F., Henry R., Macleod J. A., Sanderson J. B. and Sturz. A. V. 2003. Effect of compost and manure soil amendments on nematodes and on yields of potato and barley. Journal of Nematology 35:289-293.

24. Mulrooney R. P. 2004. Nematode control suggestions for vegetables. University of Delaware, College of Agriculture \& Natural Resources.

25. Onkendi E. M., Kariuki G. M., Marais M. and Moleleki L. N. 2014. The threat of root -knot nematodes (Meloidogyne spp.) in Africa: a review. Plant Pathology 63:727-737.

26. Perry R. N. and Moens M. 2013. Plant nematology $2^{\text {nd }}$ edition. CABI, Wallingford, UK.

27. Perry R. N., Moens M. and Starr J. L. 2009. Root-knot nematodes (ed.). CABI, Wallingford, UK.

28. Perry E. J. and Ploeg A. T. 2010. How to Manage Pests: Pests in Gardens and Landscapes (Nematodes). Statewide IPM program, Agriculture and Natural Resources, University of California. 5p. 
29. Rich J. R., Andersen P. C. and Dunn R. A. 2006. Nematodes of backyard deciduous fruit crops in Florida. EDIS Electronic Data Information Source of UF/IFAS Extension, ENY-055.

30. Walker G. E. 2004. Effects of Meloidogyne javanica and organic amendments, inorganic fertilisers and nematicides on carrot growth and nematode abundance. Nematologia Mediterranea 32:181-188.

31. Whitehead A. G. 1997. Plant nematode control. Rhone-poulenc publishing, 380p.

32. Yepsen R. B. Jr. (ed.) 1984. The encyclopedia of natural insect \& disease control. Rodale Press, Emmaus, PA. 267-271.

33. Yunzhong L. 2007. Experiment on prevention and control of pomegranate rootknot nematodes disease. Journal of South China Fruits 36:80-94. 